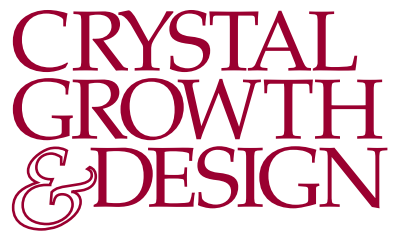

\title{
Bond Formation upon Water Removal in an Unusual "Pseudo"- 2 Topotactic Reaction Investigated by Single-Crystal Structure and in Situ Synchrotron X-ray Powder Diffraction Analysis
}

\author{
4 Joanna Dopta, ${ }^{\dagger}$ Anna-Lena Hansen, ${ }^{\dagger}$ Nicole Pienack, ${ }^{\dagger}$ Lisa K. Mahnke, ${ }^{\dagger}$ Helge Reinsch, ${ }^{\dagger}$ Martin Etter, ${ }^{\dagger}$ \\ ${ }_{5}$ Christian Näther, ${ }^{\dagger}$ and Wolfgang Bensch* ${ }^{*}{ }^{\dagger}$ (i) \\ ${ }^{\dagger}$ Institute for Inorganic Chemistry, Christian-Albrechts-University of Kiel, Max-Eyth-Str. 2, 24118 Kiel, Germany \\ 7 Deutsches Elektronen-Synchrotron, Notkestr. 85, D-22607 Hamburg, Germany
}

9 ABSTRACT: The new compound $\left[\mathrm{Cu}(\right.$ cyclam $\left.)\left(\mathrm{H}_{2} \mathrm{O}\right)\right]$ $10\left\{[\mathrm{Cu}(\text { cyclam })]_{2}\left[\mathrm{HTiNb}_{9} \mathrm{O}_{28}\right]\right\} \cdot 26 \mathrm{H}_{2} \mathrm{O}$ (1) (cyclam $=$ 11 1,4,8,11-tetraazacyclotetradecane) was obtained under solvo12 thermal conditions. Its crystal structure contains a mono13 titano-nonaniobate anion in which one position is equally 14 occupied by $\mathrm{Nb}(\mathrm{V})$ and $\mathrm{Ti}(\mathrm{IV})$. The anions are expanded by $15[\mathrm{Cu}(\mathrm{cyclam})]^{2+}$ cations via $\mathrm{Nb}-\mathrm{O}-\mathrm{Cu}$ bridges generating $16\left\{[\mathrm{Cu}(\text { cyclam })]_{2}\left[\mathrm{HTiNb}_{9} \mathrm{O}_{28}\right]\right\}^{2-}$ cluster units, which are 17 arranged into layers. Between these layers there are addition18 ally isolated $\left[\mathrm{Cu}(\mathrm{cyclam})\left(\mathrm{H}_{2} \mathrm{O}\right)_{2}\right]^{2+}$ cations as well as hydrate 19 water molecules. Storage of $\mathbf{1}$ at room temperature leads to

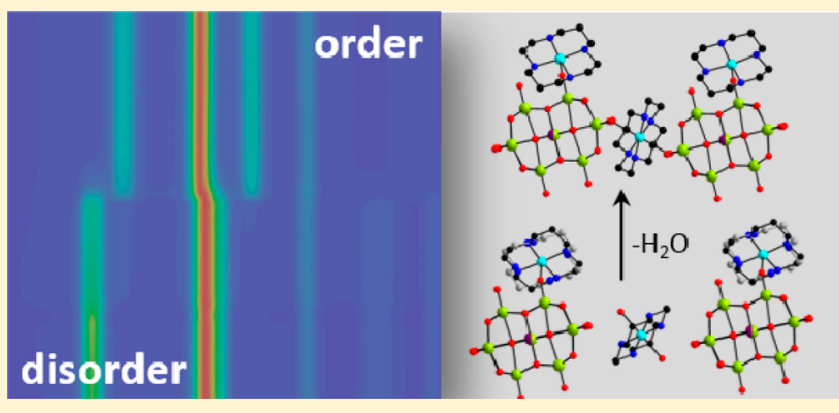
loss of $\sim 13$ water molecules, and a new crystalline phase (2) crystallizes that, with heating, transforms into the anhydrate. The reversibility of this reaction was investigated by thermogravimetry and X-ray powder diffraction (XRPD). Temperaturedependent in situ synchrotron XRPD investigations prove an abrupt phase transition, in which especially the $a$ axis is dramatically shortened and the $\left\{[\mathrm{Cu}(\mathrm{cyclam})]_{2}\left[\mathrm{HTiNb}_{9} \mathrm{O}_{28}\right]^{2-}\right\}$ cluster is rearranged. Single-crystal X-ray diffraction of 2 reveals that, despite the unusual large shrinking of the unit cell volume, the domains formed by water removal exhibit some preferred orientation close to that expected for a topotactic reaction, which allowed the performance of a structure analysis. In the structure of 2, the two water molecules of the isolated $\left[\mathrm{Cu}(\mathrm{cyclam})\left(\mathrm{H}_{2} \mathrm{O}\right)_{2}\right]^{2+}$ cation in $\mathbf{1}$ are replaced by two terminal cluster $\mathrm{O}$ atoms, leading to the formation of chains via $\mathrm{Nb}-\mathrm{O}-\mathrm{Cu}$ bonds, and this phase transition is accompanied by an ordering of one of the two cyclam ligands.

30 Solid compounds containing crystal water molecules are 31 potentially precursors or educts for the preparation of new, 32 water-deficient crystalline phases by, for example, directed 33 thermal decomposition reactions. A very prominent example is $34 \mathrm{CuSO}_{4} \cdot 5 \mathrm{H}_{2} \mathrm{O}$, which can be thermally dehydrated in three 35 distinct steps including formation of the crystalline inter36 mediates $\mathrm{CuSO}_{4} \cdot 3 \mathrm{H}_{2} \mathrm{O}, \mathrm{CuSO}_{4} \cdot \mathrm{H}_{2} \mathrm{O}$, and $\mathrm{CuSO}_{4}{ }^{1-3}$ Another 37 example is $\mathrm{CaSO}_{4} \cdot 2 \mathrm{H}_{2} \mathrm{O}$, which can be thermally dehydrated 38 to the semihydrate and finally to anhydrite. ${ }^{4-6}$ In this context, 39 it is noted that there are an increasing number of reports that 40 deal with reversible solvent removal. ${ }^{7-11}$

41 In most cases the intermediates obtained by water removal 42 from especially more complex hydrated structures were 43 normally not structurally characterized, because only poly44 crystalline powders are obtained. Because the composition 45 changes during dehydration such reactions do not proceed via 46 a second-order single crystal to single crystal phase transition, 47 for which a crystallographically group-subgroup relation is 48 required. Usually they are of first order and proceed via 49 nucleation and growth of a new crystalline phase, leading to the formation of domains, without changing the crystal 50 morphology. In most cases there is no structural relationship 51 between the hydrate and the intermediate phase, and therefore, 52 the domains show a random orientation, and the diffraction 53 pattern corresponds to that of a powder. However, in very few 54 cases there is a strong relationship between the structures of 55 the reactant and the product, and in this case the domains 56 formed in a reaction exhibit a strong preferred orientation 57 simulating the diffraction pattern of a single crystal. The 58 presence of such a reaction, called topotactic, can only be 59 proven by single-crystal X-ray diffraction, and in ideal cases 60 differences between the diffraction pattern of the pristine and 61 the product phase are only detected in the mosaic spread. ${ }^{12-15} 62$ For such reactions the question arises what will happen if 63 larger structural changes occur for which the orientation of the 64 domains are far from perfect and if structural information can 65 be retrieved in such cases. In the course of our ongoing 66

Received: June 7, 2019

Revised: July 25, 2019

Published: August 26, 2019 
67 investigations on the synthesis and properties of new 68 polyoxometalates we found such an example.

69 Polyoxometalates (POMs; $\mathrm{M}=\mathrm{V}, \mathrm{Nb}, \mathrm{Ta}, \mathrm{Mo}$, and $\mathrm{W}$ ) are 70 an important class of compounds that is characterized by a 71 large variety of high-nuclearity cluster anions exhibiting 72 different chemical compositions, properties, shapes, sizes, and 73 topologies. ${ }^{16-30}$ In most cases POMs contain an appreciable 74 amount of water, which in several cases is emitted already at 75 room temperature. Focusing on polyoxoniobates ( $\mathrm{PONb}$ ), 76 examples include $\mathrm{K}_{12}\left[\mathrm{Ti}_{2} \mathrm{O}_{2}\right]\left[\mathrm{SiNb}_{12} \mathrm{O}_{40}\right] \cdot 16 \mathrm{H}_{2} \mathrm{O},{ }^{31}$ $77 \mathrm{Na}_{14}\left[\mathrm{H}_{2} \mathrm{Si}_{4} \mathrm{Nb}_{16} \mathrm{O}_{56}\right] \cdot 45.5 \mathrm{H}_{2} \mathrm{O},{ }^{31} \mathrm{Li}_{7} \mathrm{~K}\left[\mathrm{Nb}_{6} \mathrm{O}_{19}\right] \cdot 15 \mathrm{H}_{2} \mathrm{O},{ }^{32}$ $78 \mathrm{Li}_{13} \mathrm{~K}\left[\mathrm{SiNb}_{12}(\mathrm{OH})_{2} \mathrm{O}_{38}\right] \cdot 17 \mathrm{H}_{2} \mathrm{O},{ }^{32}$ (TMA) ${ }_{9}\left[\mathrm{~V}_{3} \mathrm{Nb}_{12} \mathrm{O}_{42}\right]$. $7918 \mathrm{H}_{2} \mathrm{O}$ (TMA = tetramethylammonium), ${ }^{33} \mathrm{Na}_{7}\left[\mathrm{HNb}_{6} \mathrm{O}_{19}\right]$. $8015 \mathrm{H}_{2} \mathrm{O},^{34}\left[\mathrm{Cu}(\mathrm{en})_{2}\left(\mathrm{H}_{2} \mathrm{O}\right)_{2}\right]_{5} \mathrm{~K}_{10}\left[\mathrm{~K}(\mathrm{GeOH})_{2} \mathrm{Ge}_{2} \mathrm{Nb}_{16} \mathrm{H}_{3} \mathrm{O}_{54}\right]_{2}$. $8138 \mathrm{H}_{2} \mathrm{O}$ (en = ethylenediamine), ${ }^{35}\left[\mathrm{Cu}(\mathrm{en})_{2}\right]_{3}\left\{\left[\mathrm{Cu}(\mathrm{en})_{2}\right]-\right.$ $\left.82\left[\mathrm{H}_{6} \mathrm{SiNb}_{18} \mathrm{O}_{54}\right]\right\} \cdot 22 \mathrm{H}_{2} \mathrm{O},{ }^{36}(\mathrm{TMA})_{5}\left[\mathrm{H}_{2} \mathrm{TeNb}_{5} \mathrm{O}_{19}\right] \cdot 20 \mathrm{H}_{2} \mathrm{O},{ }^{37}$ 83 (TMA) $)_{5}\left[\mathrm{H}_{3} \mathrm{Nb}_{6} \mathrm{O}_{19}\right] \cdot 20 \mathrm{H}_{2} \mathrm{O},{ }^{38} \mathrm{H}_{4} \mathrm{Na}_{6} \mathrm{~K}_{22} \mathrm{Cs}_{4}\left[\mathrm{H}_{4} \mathrm{Nb}_{52} \mathrm{O}_{150}\right]$. $8463 \mathrm{H}_{2} \mathrm{O},{ }^{39} \mathrm{Na}_{12}\left[\mathrm{Pt}\left(\mathrm{Nb}_{6} \mathrm{O}_{19}\right)_{2}\right] \cdot 52 \mathrm{H}_{2} \mathrm{O}$. ${ }^{40}$ We note that this 85 list of compounds is not complete, and we are also aware that $86 \mathrm{PONb}$ compounds with a lower number of crystal water 87 molecules were also reported. In most cases the thermal 88 stability and water removal of the samples was investigated 89 with thermoanalytical methods, but no further efforts were 90 undertaken to characterize partially or fully dehydrated 91 decomposition products in more detail. In some reports the 92 authors mentioned that the samples tend to lose water already 93 at room temperature when removed from the mother liquor 94 like, for example, $\left[\mathrm{N}\left(\mathrm{CH}_{3}\right)_{4}\right]_{4}\left[\mathrm{Na}_{2} \mathrm{Nb}_{10} \mathrm{O}_{28}\right] \cdot 8 \mathrm{H}_{2} \mathrm{O} \cdot 1 /$ $952 \mathrm{CH}_{3} \mathrm{OH}^{41}\left[\mathrm{~N}\left(\mathrm{CH}_{3}\right)_{4}\right]_{6}\left[\mathrm{Nb}_{10} \mathrm{O}_{28}\right] \cdot 6 \mathrm{H}_{2} \mathrm{O}^{41}$ or $96 \mathrm{Na}_{8}\left[\mathrm{Nb}_{8} \mathrm{Ti}_{2} \mathrm{O}_{28}\right] \cdot 34 \mathrm{H}_{2} \mathrm{O},{ }^{42}$ but even here no further inves97 tigations were performed. This means that the synthetic 98 potential of hydrated PONbs as starting materials for the 99 generation of new, water-deficient compounds was not 100 explored until now.

101 In this context we reported on the reversible dehydration 102 and rehydration of $\left\{\left[\mathrm{Cu}(\text { cyclam })\left(\mathrm{H}_{2} \mathrm{O}\right)\right]_{2}[\mathrm{Cu}(\text { cyclam })]_{2}-\right.$ $\left.103\left[\mathrm{Nb}_{10} \mathrm{O}_{28}\right]\right\}_{n} \cdot 9 n \mathrm{H}_{2} \mathrm{O}$ (cyclam $=1,4,8,11$-tetraazacyclotetrade104 cane), which is accompanied by a significant change of the 105 crystal structure, ${ }^{43}$ but the pristine material could be 106 recrystallized upon water uptake. In further investigations we 107 synthesized a novel compound with the composition [Cu108 (cyclam) $\left.\left(\mathrm{H}_{2} \mathrm{O}\right)_{2}\right]\left\{[\mathrm{Cu}(\text { cyclam })]_{2}\left[\mathrm{HTiNb}_{9} \mathrm{O}_{28}\right]\right\} \cdot 24 \mathrm{H}_{2} \mathrm{O}$ (1), 109 which was obtained by solvothermal reaction. After the crystals 110 were removed from the mother liquor, cocrystallized $\mathrm{H}_{2} \mathrm{O}$ 111 molecules are partially emitted, leading to formation of a new 112 compound with composition $\left\{[\mathrm{Cu}(\text { cyclam })]_{3}\left[\mathrm{HTiNb}_{9} \mathrm{O}_{28}\right]\right\}_{n}$. $113 \approx 13 \mathrm{H}_{2} \mathrm{O}(2)$ as intermediate that does not transform back 114 into $\mathbf{1}$ in a humid atmosphere. This reaction was studied using 115 different methods, including temperature-dependent in situ 116 synchrotron radiation-based X-ray powder diffraction (XRPD) 117 and single-crystal X-ray diffraction to gain detailed information 118 on the structural changes that are accompanied by this 119 reaction.

\section{EXPERIMENTAL SECTION}

121 General. All chemicals except $\mathrm{K}_{7} \mathrm{HNb}_{6} \mathrm{O}_{19} \cdot 13 \mathrm{H}_{2} \mathrm{O}$ were purchased 122 and used without further purification: 1,4,8,11-tetraazacyclotetrade123 cane (98+\%, Alfa Aesar), $\mathrm{Cu}\left(\mathrm{NO}_{3}\right)_{2} \cdot 3 \mathrm{H}_{2} \mathrm{O}$ (>99\%, Merck), Ti$124\left(\mathrm{O}^{\mathrm{i} P r}\right)_{4}\left(>98 \%\right.$, Merck). $\mathrm{K}_{7} \mathrm{HNb}_{6} \mathrm{O}_{19} \cdot 13 \mathrm{H}_{2} \mathrm{O}$ was synthesized by a 125 literature method. ${ }^{44}$ All reactions were performed under hydrothermal 126 conditions in DURAN glass tubes with an inner volume of $11 \mathrm{~mL}$ at $T$ $127=130{ }^{\circ} \mathrm{C}$ for $3 \mathrm{~h}$ under stirring. After the reaction products were 128 cooled in an ice bath, the reaction mixtures were filtered off, the 129 mother liquors were transferred into straight glass tubes, and the solvent was left to evaporate at room temperature. The resulting 130 products were washed with very small amounts of demineralized 131 water and stored in air. Larger crystals are relatively stable over a 132 longer period of time, while smaller and/or ground crystallites 133 immediately lose crystal water molecules leading to an opaque solid. 134

Synthesis. $\mathrm{K}_{7} \mathrm{HNb}_{6} \mathrm{O}_{19} \cdot 13 \mathrm{H}_{2} \mathrm{O}(0.2 \mathrm{mmol}), 0.4 \mathrm{mmol}$ of 135 $\mathrm{Cu}\left(\mathrm{NO}_{3}\right)_{2} \cdot 3 \mathrm{H}_{2} \mathrm{O}$, and $0.4 \mathrm{mmol}$ of 1,4,8,11-tetraazacyclotetradecane 136 (cyclam) were placed in a DURAN glass tube, and after addition of 3137 $\mathrm{mL}$ of $\mathrm{H}_{2} \mathrm{O}$ and $0.034 \mathrm{mmol}$ of $\mathrm{Ti}\left(\mathrm{O}^{\mathrm{i}} \mathrm{Pr}\right)_{4}$, the $\mathrm{pH}$ value was adjusted 138 with $0.2 \mathrm{~mL}$ of $1 \mathrm{M} \mathrm{KOH}$ to $\sim 11$. After slow evaporation of the 139 solvent, violet block-shaped crystals were obtained and were washed 140 with minute amounts of distilled water. Yield: $137.0 \mathrm{mg}$ (46\% based 141 on $\mathrm{Nb}$ ).

142

Single-Crystal Structure Analysis. Single-crystal X-ray intensity 143 data were collected with an STOE Imaging Plate Diffraction System 144 (IPDS-1) with Mo $\mathrm{K} \alpha$ radiation $(\lambda=0.71073 \AA$ ) at $170 \mathrm{~K}$. A 145 numerical absorption correction was performed. The crystal structures 146 were solved with SHELXS-97 $7^{45}$ and refined against $F^{2}$ using 147 SHELXL-2014. ${ }^{46}$ All non-H atoms except some of the disordered 148 water $\mathrm{O}$ atoms of lower occupancy were refined anisotropically. The 149 $\mathrm{C}-\mathrm{H}$ and $\mathrm{N}-\mathrm{H} \mathrm{H}$ atoms were positioned with idealized geometry 150 and refined isotropically with $U_{\text {iso }}(\mathrm{H})=1.2 U_{\text {eq }}(\mathrm{C})$ using a riding 151 model. The $\mathrm{O}-\mathrm{H} \mathrm{H}$ atoms were not located but considered in the 152 calculation of the molecular formula and the molecular weight. One 153 cyclam ligand in compound $\mathbf{1}$ was disordered in two orientations and 154 was refined with restraints using a split model. The water $\mathrm{O}$ atoms are 155 also disordered, and some positions were not fully occupied. For 156 compound 2 internal $R$-value as well as all other reliability factors 157 including the residual electron density are high, because the intensities 158 could not be integrated with high accuracy. Selected crystal data and 159 details of the structure refinement are listed in Table 1. 160 t1

CCDC-1919265 (1) and CCDC-1919264 (2) contain the 161 supplementary crystallographic data, which can be obtained free of 162 charge via www.ccdc.cam.ac.uk/data_request/cif. 163

Table 1. Selected Crystal Data and Details of the Structure Refinement for 1 and after Storing This Crystal for $3 \mathrm{~d}$ at Room Temperature

\begin{tabular}{|c|c|}
\hline compound & 1 \\
\hline formula & $\mathrm{C}_{30} \mathrm{H}_{125} \mathrm{Cu}_{3} \mathrm{~N}_{12} \mathrm{Nb}_{9} \mathrm{O}_{54} \mathrm{~T}$ \\
\hline $\begin{array}{l}\text { molecular weight/ } \\
\mathrm{g} \mathrm{mol}^{-1}\end{array}$ & 2593.12 \\
\hline crystal system & monoclinic \\
\hline space group & $P 2_{1} / c$ \\
\hline$a / \AA$ & $16.7690(4)$ \\
\hline$b / \AA ̊$ & $17.5766(3)$ \\
\hline$c / \AA$ & $15.6167(4)$ \\
\hline$a / \operatorname{deg}$ & 90 \\
\hline$\beta / \operatorname{deg}$ & $113.746(2)$ \\
\hline$\gamma / \operatorname{deg}$ & 90 \\
\hline$V / \AA^{3}$ & $4213.21(17)$ \\
\hline$T / K$ & $170(2)$ \\
\hline$Z$ & 2 \\
\hline$D_{\text {calc }} / \mathrm{g} \mathrm{cm}^{-3}$ & 2.044 \\
\hline$\mu / \mathrm{mm}^{-1}$ & 2.107 \\
\hline$\theta_{\max } / \operatorname{deg}$ & 26.005 \\
\hline measured refl & 38866 \\
\hline unique refl & 8257 \\
\hline $\operatorname{refl} F_{0}>4 \sigma\left(F_{0}\right)$ & 7303 \\
\hline parameter & 639 \\
\hline$R_{\text {int }}$ & 0.0270 \\
\hline$\left.R_{1}\left[F_{0}>4 \sigma F_{0}\right)\right]$ & 0.0370 \\
\hline$w R_{2}[$ all data $]$ & 0.1100 \\
\hline GOF & 1.054 \\
\hline$\Delta \rho_{\max / \min } / \mathrm{e} \AA^{-3}$ & $1.019 /-0.644$ \\
\hline
\end{tabular}

2
$\mathrm{C}_{30} \mathrm{H}_{125} \mathrm{Cu}_{3} \mathrm{~N}_{12} \mathrm{Nb}_{9} \mathrm{O}_{41} \mathrm{Ti}$
2361.94
monoclinic
$P 2_{1} / c$
$14.5725(10)$
$17.6063(7)$
$15.1513(10)$
90
$108.702(5)$
90
$3682.1(4)$
$200(2)$
2
2.130
2.387
26.005
27325
7164
5598
448
0.1553
0.1069
0.2954
1.082
$3.686 /-1.350$


164 In-House X-ray Powder Diffraction. Laboratory X-ray powder 165 patterns were recorded with $\mathrm{Cu} \mathrm{K} \alpha 1$ radiation $(\lambda=1.5406 \AA)$ in 166 transmission geometry on an STOE Stadi-P powder diffractometer 167 with a Ge monochromator and a Mythen $1 \mathrm{~K}$ detector.

168 Synchrotron X-ray Diffraction. Synchrotron XRPD was 169 performed at the PETRA III, P02.1 beamline (DESY, Hamburg), 170 between room temperature and $65{ }^{\circ} \mathrm{C}$ using a nitrogen gas blower 171 and $60 \mathrm{keV}$ radiation $(\lambda=0.20717 \AA)$. To determine the detector 172 characteristics, the sample-to-detector distance (SDD), $\mathrm{LaB}_{6}$ was used 173 as calibration standard. For XRPD, the SDD was $1012.18 \mathrm{~mm}$. The 174 samples were measured in Kapton capillaries. To obtain the water-rich 175 compound, the solid sample of the water-poor material was 176 suspended in water, and the suspension was transferred via syringe 177 into the capillaries. The integration of the scattering data was 178 performed using Fit2D. ${ }^{47}$ Desy data helper and Multi power X-ray 179 diffraction data tool for data integration and plotting were applied.

180 Spectroscopic Investigations. A Bruker Alpha-P ATR IR 181 spectrometer was used to record mid-infrared (MIR) spectra in a 182 range of $400-4000 \mathrm{~cm}^{-1}$. UV-Vis diffuse reflectance spectra were 183 collected on a UV-vis-NIR (NIR = near-infrared) two-channel 184 spectrometer Cary 5 from Carian Techtron Pty using $\mathrm{BaSO}_{4}$ as 185 reference. The IR spectrum and the band assignment are displayed in 186 the Supporting Information.

187 Elemental Analysis. CHN analyses were done with an EURO EA 188 elemental analyzer (EURO VEKTOR).

189 Thermal Analysis. Thermogravimetric data were recorded on a 190 Netzsch STA $4096 \mathrm{CD}$ in air with a heating rate of $4{ }^{\circ} \mathrm{C} / \mathrm{min}$.

\section{RESULTS AND DISCUSSION}

192 Synthetic Aspects. Because alkaline $\mathrm{pH}$ values are 193 required for the synthesis of PONbs, one strategy to obtain 194 new compounds with transition-metal (TM) complexes is to 195 prevent the formation of hydroxides by in situ complex 196 formation applying amine molecules. ${ }^{48}[\mathrm{Co}(\text { en })]^{2+}$ and $197[\mathrm{Cr}(\mathrm{en})]^{2+}$ cations were the first complexes that were used 198 as counterions in PONbs. ${ }^{49}$ In the meantime, a relatively large 199 number of PONbs containing $\mathrm{Cu}^{2+}$-centered complexes were 200 reported, which may be due to the high stability constants of $201 \mathrm{Cu}^{2+}$ amine complexes and the Jahn-Teller distortion of $\mathrm{Cu}^{\mathrm{II}}$, 202 which results in flexible coordination geometries. ${ }^{50}$

203 The title compound was obtained at $130{ }^{\circ} \mathrm{C}$ after a reaction 204 time of $3 \mathrm{~h}$. The slurry was stirred during the reaction, and the 205 product crystallized as a violet microcrystalline powder and 206 could be recovered by filtration immediately after solvothermal 207 treatment. Single crystals were grown either by keeping the 208 filtrate at room temperature for several days, allowing the 209 solvent to evaporate slowly, or by heating the mixture of the 210 starting materials hydrothermally without stirring.

211 Crystal Structure of 1. $\left[\mathrm{Cu}(\right.$ cyclam $\left.)\left(\mathrm{H}_{2} \mathrm{O}\right)_{2}\right]\{[\mathrm{Cu}-$ 212 (cyclam) $\left.]_{2}\left[\mathrm{HTiNb}_{9} \mathrm{O}_{28}\right]\right\} \cdot 24 \mathrm{H}_{2} \mathrm{O}$ (1) crystallizes in the 213 monoclinic space group $P 2_{1} / c$ with two formula units in the 214 unit cell (Table 1). All atoms, except $\mathrm{Cu} 2$, are located on 215 general positions. The structure consists of the monotitano216 nonaniobate $\left[\mathrm{HTiNb}_{9} \mathrm{O}_{28}\right]^{6-}$ anion and two crystallographi217 cally independent $\left[\mathrm{Cu}(\text { cyclam })\left(\mathrm{H}_{2} \mathrm{O}\right)_{2}\right]^{2+}(x=0,1)$ cations 218 (Figure 1).

219 The anion is composed of $10 \mathrm{Ti} / \mathrm{NbO}_{6}$ octahedra sharing 220 common edges, with the central positions occupied with $50 \%$ $221 \mathrm{Nb}^{\mathrm{V}}$ and $\mathrm{Ti}^{\mathrm{IV}}$. Bond valence sum (BVS) calculations reveal 222 oxidations states of +5 for $\mathrm{Nb}$ and +4 for $\mathrm{Ti}$ and indicate that 223 the cluster is monoprotonated; a BVS analysis provides an 224 average value of 1.6 for the terminal $\mathrm{O}$ atoms (Table S1), and 225 therefore it is highly likely that the proton is spread over these 226 atoms, which is not unusual in polyoxometalate chemistry.

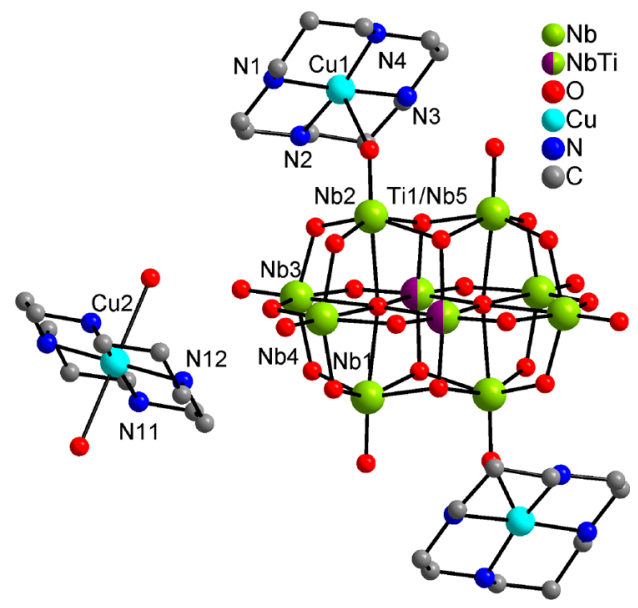

Figure 1. View of the structural units in $\mathbf{1}$. The disorder of the cyclam molecule is not displayed, $\mathrm{H}$ atoms are omitted, and only selected atoms are labeled.

The geometric parameters, $\mathrm{Ti} / \mathrm{Nb}-\mathrm{O}$ bonds, and $\mathrm{O}-\mathrm{Ti} / 227$ $\mathrm{Nb}-\mathrm{O}$ angles are in the range reported in literature (Table 228 $\mathrm{S} 2) .{ }^{41,51-53}$ The $\left[\mathrm{HTiNb}_{9} \mathrm{O}_{28}\right]^{6-}$ anion is decorated by two 229 symmetry-equivalent $[\mathrm{Cu}(\text { cyclam })]^{2+}$ complexes via $\mathrm{Nb}-\mathrm{O}-230$ $\mathrm{Cu}$ bridges ( $\mathrm{Cu} 1-\mathrm{O} 5$ : $2.342(3) \AA)$, thus forming $\{[\mathrm{Cu}-231$ (cyclam) $\left.]_{2}\left[\mathrm{HTiNb}_{9} \mathrm{O}_{28}\right]^{2-}\right\}$ cluster anions. The $\mathrm{Cu} 1 \mathrm{~N}_{4} \mathrm{O} 232$ square pyramid is slightly distorted as evidenced by the angles 233 around the $\mathrm{Cu}^{2+}$ cation (Table S3). The corresponding cyclam 234 molecule is disordered and was refined using a split model. 235 The second crystallographically independent $\mathrm{Cu}^{2+}$ cation is in 236 a distorted octahedral coordination of the four $\mathrm{N}$ atoms of the 237 cyclam ligand and two $\mathrm{H}_{2} \mathrm{O}$ molecules (Table S3). The 238 $\left\{[\mathrm{Cu}(\text { cyclam })]_{2}\left[\mathrm{HTiNb}_{9} \mathrm{O}_{28}\right]\right\}$ clusters are arranged in layers 239 parallel to the $b / c$-plane, which are separated by crystal water 240 molecules and $\left[\mathrm{Cu}(\text { cyclam })\left(\mathrm{H}_{2} \mathrm{O}\right)_{2}\right]^{2+}$ cations (Figure 2$)$.

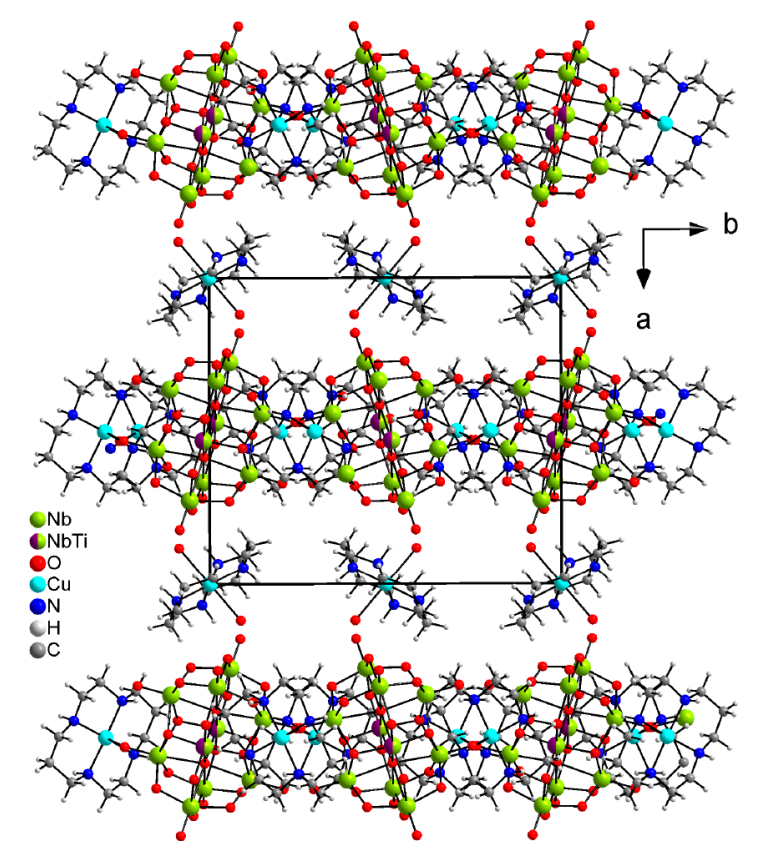

Figure 2. Crystal structure of 1 with view along the $c$-axis. The disorder of the cyclam ligand and the $\mathrm{O}$ atoms of $\mathrm{H}_{2} \mathrm{O}$ molecules are not shown. 
242 Within the layers, each $\left\{\mathrm{HTiNb}_{9} \mathrm{O}_{28}\right\}$ cluster is surrounded 243 by four $\mathrm{Cu}^{2+}$ cations in a square-planar manner (Figure 3 ) with

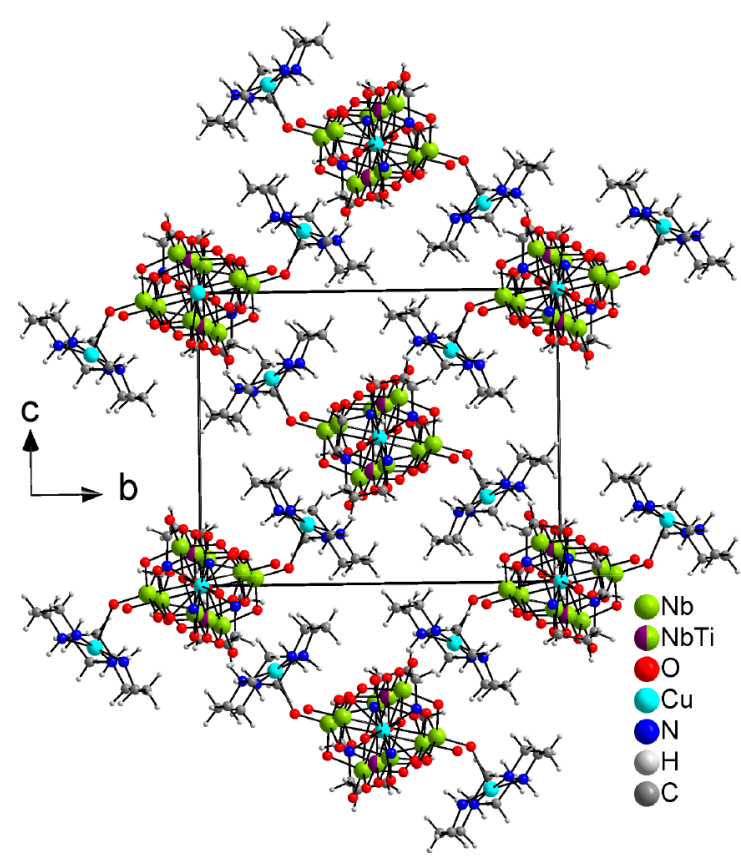

Figure 3. View of the crystal structure of $\mathbf{1}$ along the crystallographic $a$-axis. The disorder of the cyclam ligand and the water molecules are omitted.

244 the nearest possible distance being too long for bonding 245 interactions ( $\mathrm{Cu} 1-09$ : $3.70 \AA$ ). A more detailed structure 246 description with additional drawings is provided in the 247 Supporting Information and Figures S1-S4.

248 Investigations on the Stability and Water Removal of 249 1. To investigate the stability of $\mathbf{1}$ a sample of this compound 250 was placed on a balance leading immediately to a continuous 251 decrease of the sample mass. Therefore, pure samples of 1 can 252 only be obtained if the samples are immersed in a tiny amount 253 of water as shown by XRPD (Figure S5). If the residue 254 obtained after storing compound $\mathbf{1}$ at ambient conditions is 255 investigated by XRPD, obviously significant changes took 256 place, indicative from the formation of a new crystalline phase 257 (2) (Figure S6), also confirmed by time-dependent in-house 258 XRPD measurements (Figure 4).

259 If 2 residue is stored in a humid atmosphere no 260 transformation into $\mathbf{1}$ is observed, indicating that this process 261 is not reversible under these conditions (Figure S7). However, 262 compound 2 can be transformed back into $\mathbf{1}$ by submersing 263 the sample in a water-filled glass tube overnight, protecting the 264 sample by adhesive tape and immediately measured or by 265 suspending the compound in a small amount of water and 266 transferring it into Kapton capillaries. Note that only minute 267 amounts of water were used, because the compound is soluble 268 in water. Both approaches yielded samples showing XRPD 269 patterns similar to that calculated from single-crystal data for $\mathbf{1}$ 270 (Figure 4 and Figure S7).

271 Thermogravimetric (TG) measurements of the new phase 2 272 to $975{ }^{\circ} \mathrm{C}$ show three reasonable resolved mass loss steps of $273 \sim 10.2,23.0$, and $2 \%$ (Figure S8). From the derivative 274 thermogravimetry (DTG) curve it is indicated that the first 275 reaction consists of several steps that cannot be successfully 276 resolved. The mass loss in the first step corresponds to that

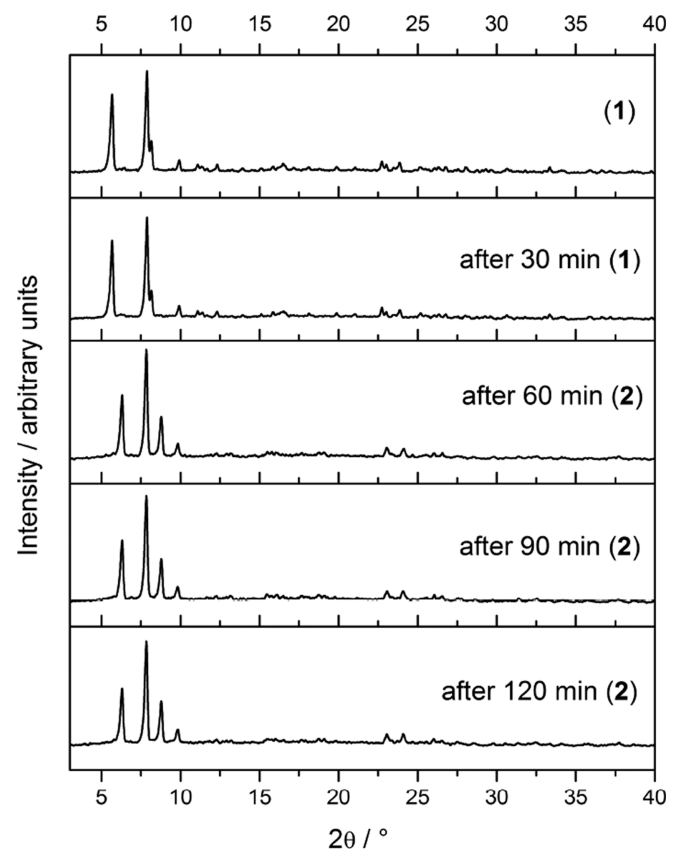

Figure 4. Time-dependent XRPD patterns of $\mathbf{1}$.

calculated for the endothermic removal of $\sim 13$ water 277 molecules $\left(\Delta m_{\text {calc }}\left(-13 \mathrm{H}_{2} \mathrm{O}\right)=9.9 \%\right)$. Therefore, compound 278 2 should represent a trideca hydrate, which is in reasonable 279 agreement with the results of an elemental analyses (calcd: C 280 15.3, H 4.2, N 7.1; found: C 15.0, H 4.0, N 7.0\%).

281

To investigate the anhydrate formed by the water removal a 282 second TG run was performed and stopped at $\sim 150{ }^{\circ} \mathrm{C}$, where 283 all the water is removed. XRPD investigations reveal that the 284 powder pattern is completely different from those of $\mathbf{1}$ and 2, 285 indicating enormous structural changes (Figure S9). However, 286 stirring the anhydrate in $\mathrm{H}_{2} \mathrm{O}$ results in formation of $\mathbf{1}$; that is, 287 this structural change is reversible (Figure S10).

288

In Situ Temperature-Resolved Synchrotron XRPD 289 Investigations. To investigate the transition of $\mathbf{1}$ into $\mathbf{2}$ in 290 more detail, experiments using in situ temperature-dependent 291 X-ray diffraction were performed. Therefore, a sample of 1292 immersed in tiny amounts of water (see Experimental Section 293 for details) were heated to $40{ }^{\circ} \mathrm{C}$, and the temperature was 294 increased in steps of $2{ }^{\circ} \mathrm{C}$ (Figure 5). The XRPD patterns 295 fs collected at room temperature and at $40{ }^{\circ} \mathrm{C}$ prove the presence 296 of compound 1. Up to $\sim 50{ }^{\circ} \mathrm{C}$ the reflections do not exhibit 297 significant shifts, but the 100 reflection shows an intensity 298 fading. Between 52 and $54{ }^{\circ} \mathrm{C}$ reflections of 1 disappear, and 299 new reflections occur. Further heating of the sample to $60{ }^{\circ} \mathrm{C} 300$ induces no further changes of the XRPD pattern. The abrupt 301 change of the powder patterns during the transformation of 1302 into $\mathbf{2}$ is surprising, because as mentioned above such 303 transitions usually proceed via nucleation and growth of a 304 new phase for which some nucleation energy is needed, and 305 because each nuclei has its own predetermined transition 306 temperature, usually both phases coexist over a larger 307 temperature range.

After it was heated to $65{ }^{\circ} \mathrm{C}$, the sample was cooled to room 309 temperature leading to no changes in the XRPD pattern, which 310 indicates that this reaction is irreversible (Figure S11). 311

However, the changes of the lattice parameters XRPD 312 patterns were evaluated by Pawley refinements (Figure 6). $313 \mathrm{f} 6$ When heated to $44{ }^{\circ} \mathrm{C}$, especially the $b$ - and $c$-axes as well as 314 


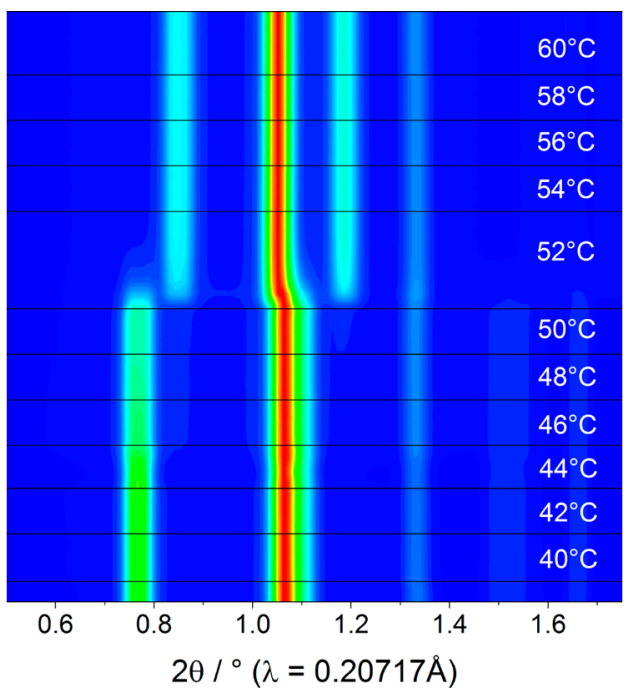

Figure 5. Evolution of the reflection intensities with increasing temperature recorded on a sample of compound 1 suspended in water when heated from 40 to $60{ }^{\circ} \mathrm{C}$. Note that the pattern at $T=52{ }^{\circ} \mathrm{C}$ was measured for a longer time.

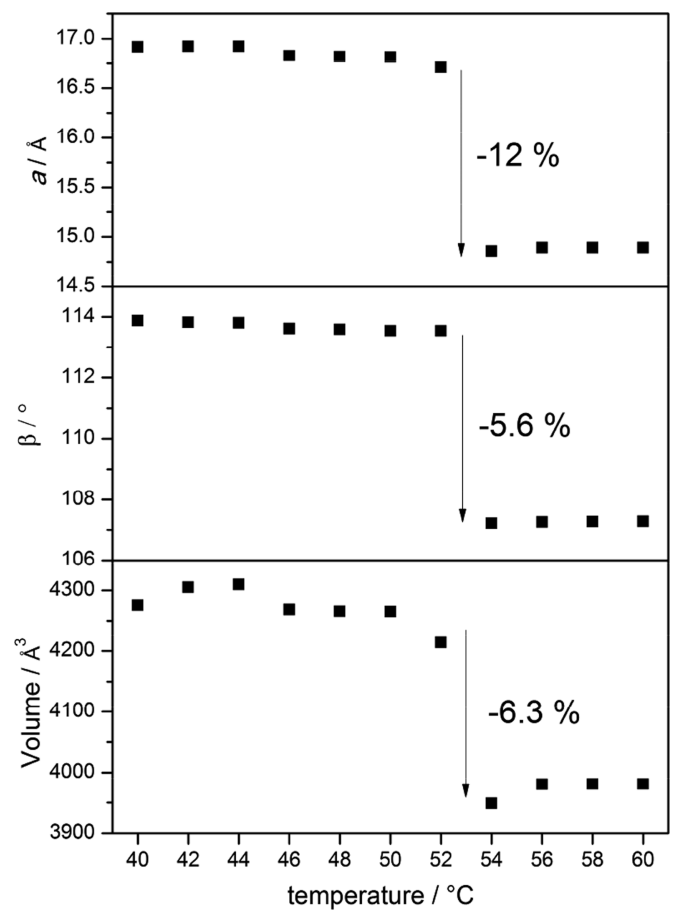

Figure 6. Changes of the $a$-axis, the angle $\beta$, and the unit cell volume as a function of temperature for $\mathbf{1}$. Given is the change (in \%). For the other parameters see Figure S12.

315 the unit cell volume slightly increase because of thermal 316 expansion (Figure 6 and Figure S12). At $\sim 46{ }^{\circ} \mathrm{C}$ there is a 317 small anomaly, which can be seen especially in the changes of 318 the $c$-axis and which is accompanied by a very small decrease of 319 the unit cell volume. It is difficult to decide whether these 320 changes are within the experimental error or if a further 321 transition is involved. At $\sim 51{ }^{\circ} \mathrm{C}$ the structure changes 322 abruptly, obviously because of the water removal leading to 323 discontinuous change of the unit cell volume typical for a first324 order phase transition. During this reaction especially the $a$ - axis and the angle $\beta$ decreases dramatically, whereas the lengths 325 of the $b$-axis increases (Figure 6).

X-ray Single-Crystal Investigations. The in situ XRPD 327 investigations reveal that the water removal leads to a dramatic 328 change of the unit cell parameters, which indicates enormous 329 structural changes during the phase transition. Therefore, one 330 would assume that there is no strong relationship between the 331 crystal structures of $\mathbf{1}$ and 2, which means that this reaction 332 should not be topotactic. However, a closer look reveals that 333 especially the interlayer distance decreases as indicated by the 334 abrupt shortening of the $a$-axis and that the cations within 335 these layers are rearranged, which can be seen by the change of 336 the angle $\beta$. Therefore, the overall structural changes might be 337 much smaller than expected, which means that both structures 338 might be related and that also no change of the space group 339 might be required. To investigate this question in more detail, 340 data collection of a crystal of $\mathbf{1}$ was performed, and after this 341 crystal was stored at room temperature for $3 \mathrm{~d}$, the 342 measurement was repeated again. Surprisingly, this crystal 343 still diffracted, but the overall crystallinity was very poor, and 344 all reflections were extremely broadened. This is especially 345 obvious by comparison of reciprocal space plots before and 346 after storage, but it is indicated that after water removal some 347 order is still present (Figure 7 and Figures S13-S15). $348 \mathrm{f} 7$

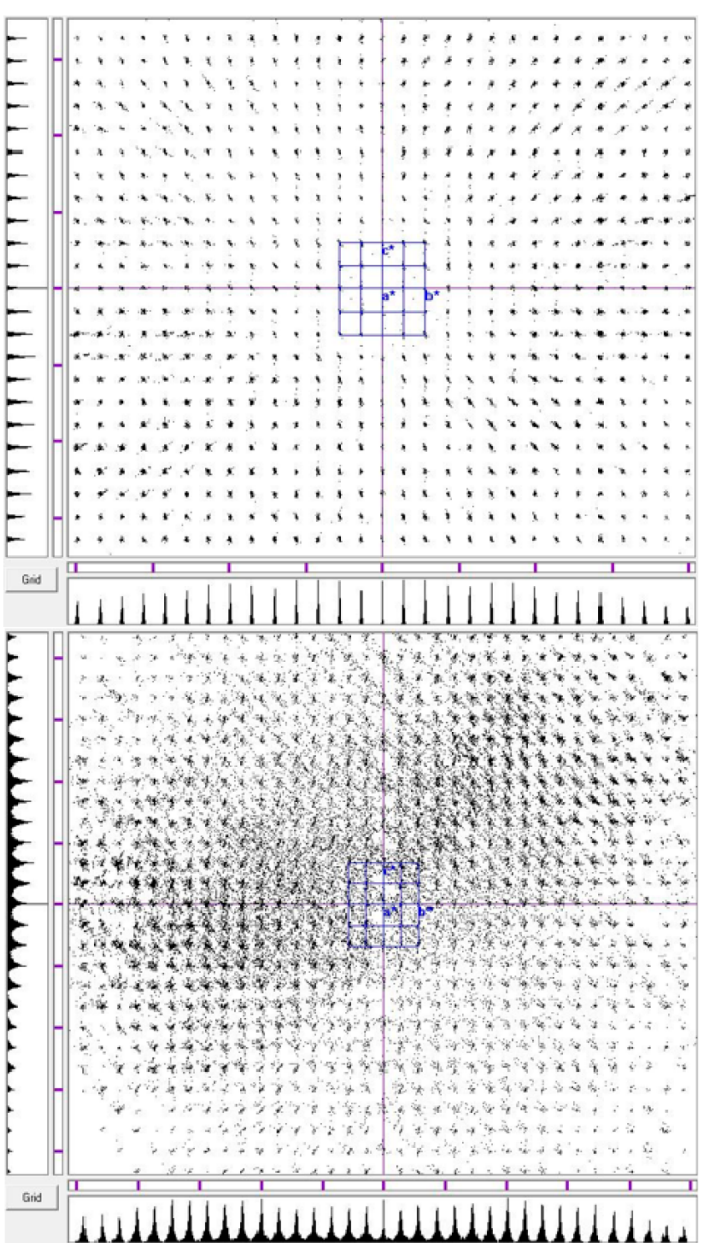

Figure 7. Reciprocal space plot along [100] for a crystal before (top) and after (bottom) storage in air for $3 \mathrm{~d}$. Please note that each dot corresponds to one reflection with $I>2 \sigma(I)$. For reciprocal space plots in the other directions see Figures S13-S15. 
349 This pattern is far from that of a single crystal, which would 350 be expected in the case of a topotactic reaction, and therefore, 351 we call this a pseudotopotactic reaction. Indexing of this 352 pattern leads to a unit cell that is very similar to that obtained 353 by XRPD, which indicates that compound $\mathbf{2}$ has formed 354 (Table 1). The change in the unit cell volume is significantly 355 larger than that obtained from the powder measurements, but 356 it should be kept in mind that the XRPD measurements were 357 performed at slightly elevated temperatures, where some 358 thermal expansion already took place and that, in the geometry 359 used for the synchrotron measurements, some deviations in the 360 unit cell parameters can occur. However, it is obvious that 361 correct integration of the intensities is difficult to achieve, and 362 therefore, several different data sets were generated using 363 different sizes of the integration box and different values for the 364 mosaic spread, until the best reliability factors were obtained. 365 The structure cannot be refined using the atomic 366 coordinates of $\mathbf{1}$ as starting model, but the structure could 367 be easily solved in space group $P 2_{1} / c$, and data refinement 368 leads to a very similar structure model as that observed for $\mathbf{1}$. 369 The water content determined by single-crystal X-ray structure 370 analysis is in good agreement with that determined by 371 thermogravimetry. Surprisingly, the cyclam ligand, which is 372 significantly disordered in $\mathbf{1}$, is fully ordered in $\mathbf{2}$. Moreover, 373 not only some of the hydrate water molecules located between 374 the layers are removed but also the two axial $\mathrm{H}_{2} \mathrm{O}$ ligands of 375 the $\left[\mathrm{Cu}(\text { cyclam })\left(\mathrm{H}_{2} \mathrm{O}\right)_{2}\right]^{2+}$ cations have been emitted, and the 376 octahedral coordination is retained by bond formation 377 between this $\mathrm{Cu}^{2+}$ cation and two terminal $\mathrm{O}$ atoms of two 378 neighbored $\left\{[\mathrm{Cu}(\text { cyclam })]_{2}\left[\mathrm{HTiNb}_{9} \mathrm{O}_{28}\right]^{2-}\right\}$ anions, trans379 forming the molecular structure into a one-dimensional 380 network (Figure 8). The basicity of cluster $\mathrm{O}$ atoms is

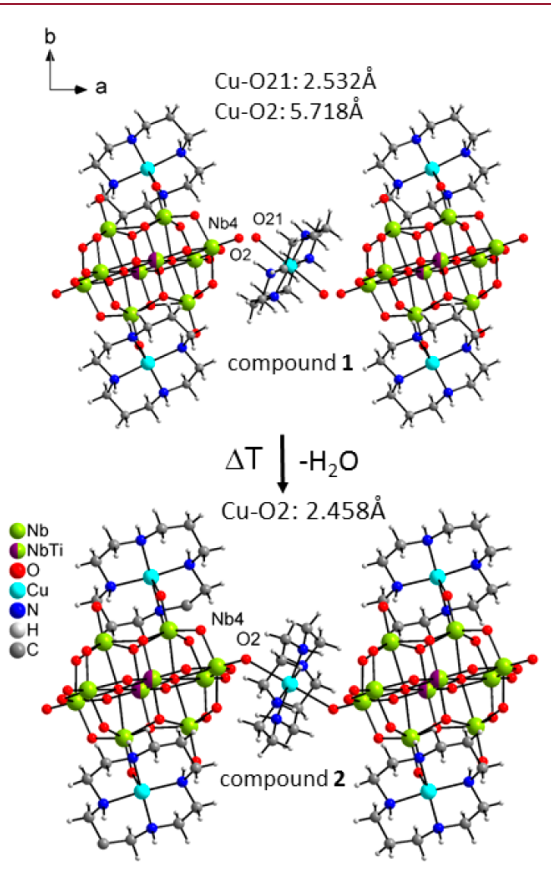

Figure 8. View of the structural changes during the transformation of 1 into 2.

381 estimated from oxygen exchange rates accessible from ${ }^{17} \mathrm{O}$ 382 NMR studies. Such studies were conducted on mono-, 383 dititanoniobate, and decaniobate anions ${ }^{54-56}$ demonstrating 384 that terminal $\mathrm{O}$ atoms are the most basic ones. In agreement with this result the coordination of $\mathrm{Cu}^{2+}$ cations occurs to 385 terminal $\mathrm{O}$ atoms of the cluster anion.

In 2 also a typical Jahn-Teller distortion is observed, but it 387 is less pronounced than in compound 1 . The $\mathrm{Cu}-\mathrm{O}$ bond 388 length is reduced from $2.532 \AA$ in 1 to $2.349(8) \AA$ in 2,389 indicating a much stronger interaction (Figure 8). Bond 390 valence sum calculations revealed similar results as for $\mathbf{1}$ (Table 391 S4), and the bond lengths and all geometrical parameters are 392 also comparable to those obtained for $\mathbf{1}$ (Tables S5 and S6). It 393 is noted that in $\mathbf{2}$ the distance between the $\mathrm{Cu}$ (II) cation and 394 the terminal $\mathrm{O}$ atom that is involved in bond formation 395 amounts to 2.349 (8) $\AA$, which rationalizes the enormous 396 structural changes accompanied by the water removal (Figure 397 8). The dramatic decrease of the interlayer distance, the much 398 stronger $\mathrm{Cu}-\mathrm{O}$ interaction, and the ordering of the cyclam 399 ligand strongly indicate that compound $\mathbf{2}$ is much more stable 400 than compound $\mathbf{1}$, and this might be the reason why no 401 retransformation of $\mathbf{2}$ into $\mathbf{1}$ is observed if the sample is stored 402 in a humid atmosphere. However, the structural reorganization 403 generates chains with composition $\left\{[\mathrm{Cu}(\text { cyclam })]_{3}-404\right.$ $\left.\left[\mathrm{HTiNb}_{9} \mathrm{O}_{28}\right]\right\}_{n}$, which are directed along [100] (Figure 9). $405 \mathrm{fg}$

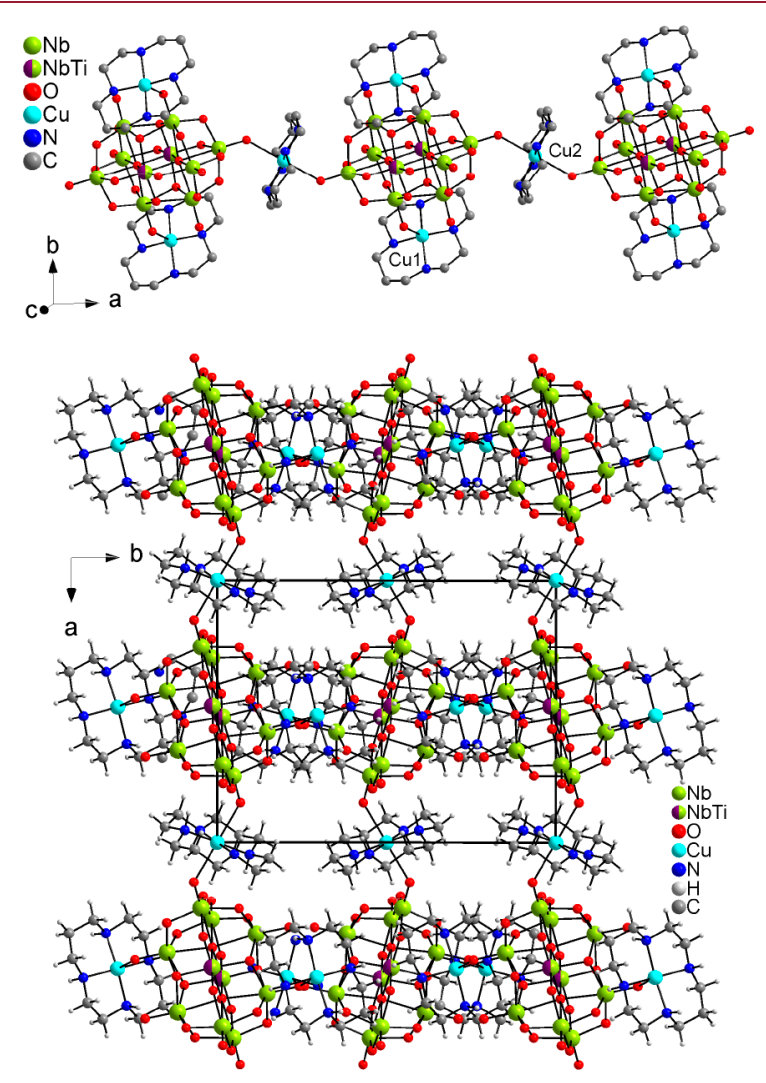

Figure 9. View of chains in $\mathbf{2}$ (top) and of the crystal structure of $\mathbf{2}$ along the crystallographic $c$-axis. $\mathrm{H}$ atoms as well as $\mathrm{O}$ atoms of $\mathrm{H}_{2} \mathrm{O}$ molecules are omitted.

\section{CONCLUSIONS}

A new monotitano-nonaniobate compound (1) is reported 407 consisting of $\left.\{\mathrm{Cu}(\text { cyclam })]_{2}\left[\mathrm{HTiNb}_{9} \mathrm{O}_{28}\right]^{2-}\right\}$ anions that are 408 arranged in layers, which are charge balanced by [Cu(cyclam)- 409 $\left.\left(\mathrm{H}_{2} \mathrm{O}\right)_{2}\right]^{2+}$ cations that are located between the layers together 410 with additional hydrate water molecules. The water can be 411 removed, and this process occurs via a water-deficient phase as 412 intermediate (2). XRPD investigations show a dramatic change 413 
414 of the unit cell parameters indicating enormous structural 415 changes, additionally indicating that predominantly the 416 interlayer distance is shortened and that the anions within 417 the layers rearrange and that therefore some structural relation 418 should be present. Therefore, the water removal was 419 investigated by single-crystal X-ray diffraction and, even if 420 the diffraction pattern is far from that expected for a topotactic 421 reaction, some order is present. A reasonable structure model 422 was found for the intermediate phase, which especially shows 423 that the coordinated water molecules of the isolated $\mathrm{Cu}^{2+}$ 424 cation are replaced by terminal $\mathrm{O}$ atoms of the cluster, leading 425 to the formation of chains and that the cyclam ligand that is 426 disordered in $\mathbf{1}$ is fully ordered in $\mathbf{2}$. Concerning the reaction 427 mechanism occurring during the transformation of $\mathbf{2}$ into $\mathbf{1}$ in 428 the presence of tiny amounts of water we cannot definitely 429 exclude that crystals of $\mathbf{2}$ are partially dissolved and $\mathbf{1}$ 430 recrystallizes from solution.

431 The present results suggest that new polyoxometalate 432 compounds may be accessible by removal of solvent molecules 433 that cannot be prepared applying other synthetic approaches. 434 Moreover, we also presented a rare example that, even in those 435 cases where, for example, XRPD indicates large structural 436 changes, some structural relations and a smooth reaction 437 pathway might be present, which in such a case should 438 preferably be investigated by single-crystal X-ray diffraction.

\section{ASSOCIATED CONTENT}

\section{S Supporting Information}

441 The Supporting Information is available free of charge on the 442 ACS Publications website at DOI: 10.1021/acs.cgd.9b00727.

443 Tables with selected bond lengths and angles, results of $444 \quad$ BVS analyses, drawings of the structures, X-ray powder 445 patterns, results of Pawley fits, TG, DTG, and DTA 446 curves, and reciprocal space plots (PDF)

\section{Accession Codes}

448 CCDC 1919264-1919265 contain the supplementary crys449 tallographic data for this paper. These data can be obtained 450 free of charge via www.ccdc.cam.ac.uk/data_request/cif, or by 451 emailing data_request@ccdc.cam.ac.uk, or by contacting The 452 Cambridge Crystallographic Data Centre, 12 Union Road, 453 Cambridge CB2 1EZ, UK; fax: +44 1223336033.

\section{AUTHOR INFORMATION}

455 Corresponding Author

456 *E-mail: wbensch@ac.uni-kiel.de.

457 ORCID

458 Helge Reinsch: 0000-0001-5288-1135

459 Christian Näther: 0000-0001-8741-6508

460 Wolfgang Bensch: 0000-0002-3111-580X

\section{Author Contributions}

462 The manuscript was written through contributions of all 463 authors. All authors have given approval to the final version of 464 the manuscript.

\section{Notes}

466 The authors declare no competing financial interest.

\section{ACKNOWLEDGMENTS}

468 Financial support by the State of Schleswig-Holstein is 469 gratefully acknowledged. Many thanks to DESY (Hamburg, 470 Germany) for allocation of beamtime. Many thanks to Dr.
Milan Köppen for providing the software to analyze the DESY 471 data.

\section{REFERENCES}

(1) Frost, G. B.; Campbell, R. A. The Rate of Dehydration of 474 Copper Sulphate Pentahydrate At Low Pressures of Water Vapor. 475 Can. J. Chem. 1953, 31, 107-119.

(2) Garner, W. E.; Pike, H. V. Dehydration Nuclei on Crystals of 477 Copper Sulphate Pentahydrate. J. Chem. Soc. 1937, 1565-1568. 478

(3) Garner, W. E.; Tanner, M. G. X. -The dehydration of copper 479 sulphate pentahydrate. J. Chem. Soc. 1930, 0, 47-57. 480

(4) Weiser, H. B.; Milligan, W. O.; Ekholm, W. C. The Mechanism 481 of the Dehydration of Calcium Sulfate Hemihydrate. J. Am. Chem. Soc. 482 1936, 58, 1261-1265.

483

(5) Putnis, A.; Winkler, B.; Fernandez-Diaz, L. In situ IR 484 spectroscopic and thermogravimetric study of the dehydration of 485 gypsum. Mineral. Mag. 1990, 54, 123-128.

(6) Razouk, R. I.; Salem, A. S.; Mikhail, R. S. The Sorption of Water 487 Vapor on Dehydrated Gypsum. J. Phys. Chem. 1960, 64, 1350-1355. 488

(7) Férey, G. A selective magnetic sponge. Nat. Mater. 2003, 2, 489 136-137.

(8) Nowicka, B.; Reczyński, M.; Rams, M.; Nitek, W.; Żukrowski, J.; 491 Kapusta, C.; Sieklucka, B. Hydration-switchable charge transfer in the 492 first bimetallic assembly based on the $[\mathrm{Ni}(\text { cyclam })]^{3+}$-magnetic $\mathrm{CN}-493$ bridged chain $\left\{\left(\mathrm{H}_{3} \mathrm{O}\right) \mathrm{Ni}^{\mathrm{III}}(\right.$ cyclam $\left.\left.) \mathrm{Fe}^{\mathrm{II}}(\mathrm{CN})_{6}\right] \cdot 5 \mathrm{H}_{2} \mathrm{O}\right\}_{n}$. Chem. Com- 494 mun. 2015, 51, 11485-11488.

(9) Zhou, H.-C.; Long, J. R.; Yaghi, O. M. Introduction to metal- 496 organic frameworks. Chem. Rev. 2012, 112, 673-674.

(10) Pinkowicz, D.; Podgajny, R.; Bałanda, M.; Makarewicz, M.; 498 Gaweł, B.; Łasocha, W.; Sieklucka, B. Magnetic Spongelike Behavior 499 of 3D Ferrimagnetic $\left\{\mathrm{Mn}^{\mathrm{II}}(\mathrm{imH})_{2} \mathrm{Nb}^{\mathrm{IV}}(\mathrm{CN})_{8}\right\}_{\mathrm{n}}$ with $\mathrm{T}_{\mathrm{c}}=62 \mathrm{~K}$. Inorg. 500 Chem. 2008, 47, 9745-9747.

(11) Näther, C.; Greve, J.; Je $\beta$, I. New Coordination Polymer 502 Changing Its Color upon Reversible Deintercalation and Reinterca- 503 lation of Water. Chem. Mater. 2002, 14, 4536-4542.

(12) Schöllhorn, R.; Roer, W.; Wagner, K. Topotactic formation and 505 exchange reactions of hydrated layered tin sulfides $\mathrm{A}_{x}\left(\mathrm{H}_{2} \mathrm{O}\right)_{y} \mathrm{SnS}_{2} .506$ Monatsh. Chem. 1979, 110, 1147-1152.

(13) Harvey, M. A.; Suarez, S.; Cukiernik, F. D.; Baggio, R. The 508 topotactic dehydration of monoclinic $\left\{\left[\mathrm{Co}(\mathrm{pht})(\mathrm{bpy})\left(\mathrm{H}_{2} \mathrm{O}\right)_{2}\right] \cdot 509\right.$ $\left.2 \mathrm{H}_{2} \mathrm{O}\right\}_{n}$ into orthorhombic $\left[\mathrm{Co}(\mathrm{pht})(\mathrm{bpy})\left(\mathrm{H}_{2} \mathrm{O}\right)_{2}\right]_{n}$ (pht is phthalate 510 and bpy is 4,4'-bipyridine). Acta Crystallogr., Sect. C: Struct. Chem. 511 2014, 70, 978-982.

(14) Suckert, S.; Rams, M.; Rams, M. M.; Näther, C. Reversible and 513 Topotactic Solvent Removal in a Magnetic Ni(NCS) 2 Coordination 514 Polymer. Inorg. Chem. 2017, 56, 8007-8017.

(15) Englert, U.; Ganter, B.; Wagner, T.; et al. Reversible Topotactic 516 Hydration and Dehydration of an Europium Complex. Z. Anorg. Allg. 517 Chem. 1998, 624, 970-974.

(16) Long, D.-L.; Burkholder, E.; Cronin, L. Polyoxometalate 519 clusters, nanostructures and materials: From self assembly to designer 520 materials and devices. Chem. Soc. Rev. 2007, 36, 105-121.

(17) Long, D.-L.; Tsunashima, R.; Cronin, L. Polyoxometallate als 522 Bausteine für funktionelle Nanosysteme. Angew. Chem. 2010, 122, 523 1780-1803.

(18) Nyman, M. Polyoxoniobate chemistry in the 21st century. 525 Dalton Trans. 2011, 40, 8049-8058.

(19) Klemperer, W. G.; Marquart, T. A.; Yaghi, O. M. Neue 527 Richtungen in der Polyvanadat-Chemie: Von Käfigen und Clustern zu 528 Körben, Bändern, Schalen und Fässern. Angew. Chem. 1992, 104, 51- 529 53; Angew. Chem., Int. Ed. Engl. 1992, 31, 49-51. 530

(20) Rhule, J. T.; Hill, C. L.; Judd, D. A.; Schinazi, R. F. 531 Polyoxometalates in Medicine. Chem. Rev. 1998, 98, 327-357.

(21) Mizuno, N.; Misono, M. Heterogeneous Catalysis. Chem. Rev. 533 1998, 98, 199-218.

(22) Wutkowski, A.; Näther, C.; Kögerler, P.; Bensch, W. 535 Antimonato polyoxovanadate based three-dimensional framework 536 exhibiting ferromagnetic exchange interactions: Synthesis, structural 537 characterization, and magnetic investigation of $\{[\mathrm{Fe}-538$ 
$\left.\left.539\left(\mathrm{C}_{6} \mathrm{H}_{14} \mathrm{~N}_{2}\right)_{2}\right]_{3} \mathrm{~V}_{15} \mathrm{Sb}_{6} \mathrm{O}_{42}\left(\mathrm{H}_{2} \mathrm{O}\right)\right\} \cdot 8 \mathrm{H}_{2} \mathrm{O}$. Inorg. Chem. 2013, 52, 32805403284.

541 (23) Trends in Polyoxometalate Research; Ruhlmann, L., Schaming, 542 D., Eds.; Nova Science Publishers, Inc.: United States, 2015.

543 (24) Gumerova, N. I.; Rompel, A. Synthesis, structures and 544 applications of electron-rich polyoxometalates. Nat. Rev. Chem. 545 2018, 2, 1-20.

546 (25) Wendt, M.; Warzok, U.; Näther, C.; van Leusen, J.; Kögerler, 547 P.; Schalley, C. A.; Bensch, W. Catalysis of "outer-phase" oxygen atom 548 exchange reactions by encapsulated "inner-phase" water in $\left\{\mathrm{V}_{15} \mathrm{Sb}_{6}\right\}$ 549 type polyoxovanadates. Chem. Sci. 2016, 7, 2684-2694.

550 (26) Vilà-Nadal, L.; Cronin, L. Design and synthesis of 551 polyoxometalate-framework materials from cluster precursors. Nat. 552 Rev. Mater. 2017, 2, 1154.

553 (27) Mahnke, L. K.; Kondinski, A.; Warzok, U.; Näther, C.; van 554 Leusen, J.; Schalley, C. A.; Monakhov, K. Y.; Kögerler, P.; Bensch, W. 555 Configurational Isomerism in Polyoxovanadates. Angew. Chem., Int. 556 Ed. 2018, 57, 2972-2975.

557 (28) Structure and Bonding in Molecular Vanadium Oxides: From 558 Templates via Host-Guest Chemistry to Applications. In Polyox559 ometalate-Based Assemblies and Functional Materials. Structure and 560 Bonding; Song, Y.-F., Ed.; Springer International Publishing Group, 5612017.

562 (29) Monakhov, K. Y.; Bensch, W.; Koegerler, P. Semimetal563 functionalised polyoxovanadates. Chem. Soc. Rev. 2015, 44, 84435648483.

565 (30) Seliverstov, A.; Forster, J.; Heiland, M.; Unfried, J.; Streb, C. 566 The anion-binding polyanion: A molecular cobalt vanadium oxide 567 with anion-sensitive visual response. Chem. Commun. 2014, 50, 78405687843.

569 (31) Nyman, M.; Bonhomme, F.; Alam, T. M.; Rodriguez, M. A.; 570 Cherry, B. R.; Krumhansl, J. L.; Nenoff, T. M.; Sattler, A. M. A 571 General Synthetic Procedure for Heteropolyniobates. Science 2002, 572 297, 996-998.

573 (32) Anderson, T. M.; Thoma, S. G.; Bonhomme, F.; Rodriguez, M. 574 A.; Park, H.; Parise, J. B.; Alam, T. M.; Larentzos, J. P.; Nyman, M. 575 Lithium Polyniobates. A Lindqvist-Supported Lithium-Water Ada576 mantane Cluster and Conversion of Hexaniobate to a Discrete Keggin 577 Complex. Cryst. Growth Des. 2007, 7, 719-723.

578 (33) Son, J.-H.; Ohlin, C. A.; Larson, E. C.; Yu, P.; Casey, W. H. 579 Synthesis and Characterization of a Soluble Vanadium-Containing 580 Keggin Polyoxoniobate by ESI-MS and ${ }^{51} \mathrm{~V}$ NMR: 581 (TMA) ${ }_{9}\left[\mathrm{~V}_{3} \mathrm{Nb}_{12} \mathrm{O}_{42}\right] \cdot 18 \mathrm{H}_{2} \mathrm{O}$. Eur. J. Inorg. Chem. 2013, 2013, $582 \quad 1748-1753$

583 (34) Alam, T. M.; Nyman, M.; Cherry, B. R.; Segall, J. M.; Lybarger, 584 L. E. Multinuclear NMR Investigations of the Oxygen, Water, and 585 Hydroxyl Environments in Sodium Hexaniobate. J. Am. Chem. Soc. 586 2004, 126, 5610-5620.

587 (35) Zhang, X.; Liu, S.-x.; Li, S.-j.; Gao, Y.-H.; Wang, X.-n.; Tang, 588 Q.; Liu, Y.-w. Two Members of the $\left\{\mathrm{X}_{4} \mathrm{Nb}_{16} \mathrm{O}_{56}\right\}$ Family $(\mathrm{X}=\mathrm{Ge}, \mathrm{Si})$ 589 Based on $\left[(\mathrm{GeOH})_{2} \mathrm{Ge}_{2} \mathrm{Nb}_{16} \mathrm{H}_{2} \mathrm{O}_{54}\right]^{12-}$ and $[\mathrm{K}(\mathrm{GeOH})-$ $\left.590 \mathrm{Ge}_{2} \mathrm{Nb}_{16} \mathrm{H}_{3} \mathrm{O}_{54}\right]^{10-}$. Eur. J. Inorg. Chem. 2013, 2013, 1706-1712.

591 (36) Huang, P.; Qin, C.; Wang, X.-L.; Sun, C.-Y.; Xing, Y.; Wang, 592 H.-N.; Shao, K.-Z.; Su, Z.-M. A new organic-inorganic hybrid based 593 on the crescent-shaped polyoxoanion $\left[\mathrm{H}_{6} \mathrm{SiNb}_{18} \mathrm{O}_{54}\right]^{8-}$ and copper594 organic cations. Dalton Trans. 2012, 41, 6075-6077.

595 (37) Son, J.-H.; Wang, J.; Osterloh, F. E.; Yu, P.; Casey, W. H. A 596 tellurium-substituted Lindqvist-type polyoxoniobate showing high $\mathrm{H}_{2}$ 597 evolution catalyzed by tellurium nanowires via photodecomposition. 598 Chem. Commun. 2014, 50, 836-838.

599 (38) Fullmer, L. B.; Mansergh, R. H.; Zakharov, L. N.; Keszler, D. 600 A.; Nyman, M. $\mathrm{Nb}_{2} \mathrm{O}_{5}$ and $\mathrm{Ta}_{2} \mathrm{O}_{5}$ Thin Films from Polyoxometalate 601 Precursors: A Single Proton Makes a Difference. Cryst. Growth Des. $6022015,15,3885-3892$.

603 (39) Jin, L.; Zhu, Z.-K.; Wu, Y.-L.; Qi, Y.-J.; Li, X.-X.; Zheng, S.-T. 604 Record High-Nuclearity Polyoxoniobates: Discrete Nanoclusters $605\left\{\mathrm{Nb}_{114}\right\},\left\{\mathrm{Nb}_{81}\right\}$, and $\left\{\mathrm{Nb}_{52}\right\}$, and Extended Frameworks Based on $606\left\{\mathrm{Cu}_{3} \mathrm{Nb}_{78}\right\}$ and $\left\{\mathrm{Cu}_{4} \mathrm{Nb}_{78}\right\}$. Angew. Chem., Int. Ed. 2017, 56, 1628860716292.
(40) Shmakova, A. A.; Shiriyazdanov, R. R.; Karimova, A. R.; 608 Kompankov, N. B.; Abramov, P. A.; Sokolov, M. N. Decay of 609 Hexaniobate Complexes of $\mathrm{Mn}(\mathrm{IV})$ and $\mathrm{Pt}(\mathrm{IV})$ in Alkaline Solutions: 610 Some New Hexaniobate Salts. J. Cluster Sci. 2018, 29, 1201-1207. 611

(41) Graeber, E. J.; Morosin, B. The Molecular Configuration of the 612 Decaniobate Ion $\left(\mathrm{Nb}_{10} \mathrm{O}_{28}{ }^{6}\right)$. Acta Crystallogr., Sect. B: Struct. 613 Crystallogr. Cryst. Chem. 1977, 33, 2137-2143.

(42) Nyman, M.; Criscenti, L. J.; Bonhomme, F.; Rodriguez, M. A.; 615 Cygan, R. T. Synthesis, structure, and molecular modeling of a 616 titanoniobate isopolyanion. J. Solid State Chem. 2003, 176, 111-119. 617

(43) Dopta, J.; Krause, D.-C.; Näther, C.; Bensch, W. Controlling 618 Fast Nucleation and Crystallization of Two New Polyoxoniobates. 619 Cryst. Growth Des. 2018, 18, 4130-4139.

(44) Filowitz, M.; Ho, R. K. C.; Klemperer, W. G.; Shum, W. 621 Oxygen-17 nuclear magnetic resonance spectroscopy of polyoxome- 622 talates. 1. Sensitivity and resolution. Inorg. Chem. 1979, 18, 93-103. 623

(45) Sheldrick, G. M. SHELXS-97: Program for the Solution of Crystal 624 Structures; University of Goettingen: Goettingen, Germany, 1997. 625

(46) Sheldrick, G. M. SHELXL-2014: Program for the Refinement of 626 Crystal Structures; University of Goettingen: Goettingen, Germany, 627 2014.

(47) Hammersley, A. P. FIT2D: An Introduction and Overview; 629 ESRF97HA02T, 1997. Online at http://www.esrf.eu/computing/ 630 scientific/FIT2D/FIT2D_INTRO/fit2d.html

(48) Wu, H.-L.; Zhang, Z.-M.; Li, Y.-G.; Wang, X.-L.; Wang, E.-B. 632 Recent progress in polyoxoniobates decorated and stabilized via 633 transition metal cations or clusters. CrystEngComm 2015, 17, 6261- 634 6268.

(49) Flynn, C. M.; Stucky, G. D. Sodium-6-Niobo- 636 (ethylenediamine)cobaltate(III) and Its Chromate(III) Analog. 637 Inorg. Chem. 1969, 8, 178-180.

(50) Carlson, G. A.; McReynolds, J. P.; Verhoek, F. H. Equilibrium 639 Constants for the Formation of Ammine Complexes with Certain 640 Metallic Ions. J. Am. Chem. Soc. 1945, 67, 1334-1339. 641

(51) Shen, L.; Li, C.-H.; Chi, Y.-N.; Hu, C.-W. Zn(2,2'-bipy) $)_{2} / 642$ $\mathrm{Co}\left(2,2^{\prime} \text {-bipy }\right)_{2}$ linked decaniobate $\left[\mathrm{Nb}_{10} \mathrm{O}_{28}\right]^{6-}$ clusters-zigzag neutral 643 chains. Inorg. Chem. Commun. 2008, 11, 992-994.

(52) Niu, J.; Wang, G.; Zhao, J.; Sui, Y.; Ma, P.; Wang, J. Zero- or 645 One-Dimensional Organic-Inorganic Hybrid Polyoxoniobates Con- 646 structed from Decaniobate Units and Transition-Metal Complexes. 647 Cryst. Growth Des. 2011, 11, 1253-1261.

(53) Matsumoto, M.; Ozawa, Y.; Yagasaki, A. Reversible 649 dimerization of decaniobate. Polyhedron 2010, 29, 2196-2201. 650 (54) Villa, E. M.; Ohlin, C. A.; Rustad, J. R.; Casey, W. H. Isotope- 651 exchange dynamics in isostructural decametalates with profound 652 differences in reactivity. J. Am. Chem. Soc. 2009, 131, 16488-16492. 653 (55) Villa, E. M.; Ohlin, C. A.; Balogh, E.; Anderson, T. M.; Nyman, 654 M.; Casey, W. H. Reaction Dynamics of the Decaniobate Ion 655 $\left[\mathrm{H} x \mathrm{Nb}_{10} \mathrm{O}_{28}\right]^{(6-\mathrm{x})-}$ in Water. Angew. Chem. 2008, 120, 4922-4924. 656 (56) Villa, E. M.; Ohlin, C. A.; Casey, W. H. Oxygen-isotope 657 exchange rates for three isostructural polyoxometalate ions. J. Am. 658 Chem. Soc. 2010, 132, 5264-5272. 